J. Perinat. Med. $11(1983) 169$

\title{
The reliability of the result of the umbilical cord $\mathrm{pH}$
}

\author{
M.Pel, P.E.Treffers
}

\section{Introduction}

In modern obstetrical practice, the $\mathrm{pH}$ of the umbilical cord blood is considered as a parameter of neonatal morbidity and, by implication, as a retrospective evaluation of the quality of obstetrical care $[3,5]$. In order to determine the $\mathrm{pH}$, blood has to be taken from the umbilical vessels, stored and analysed. Various factors during these procedures (heparin concentration, temperature of storage, time-lapse from birth to blood sampling) influence the ultimate results of the $\mathrm{pH}$.

In a first study we compared the outcomes when blood was sampled and tested immediately post partum with three other procedures (sampled later and stored at room temperature, sampled from a late clamped, cool-stored segment of the umbilical cord, and sampled from the chorionic vessels of the cool-stored placenta).

In a second study we investigated various factors separately (storing of blood in syringes and in segments of the cord, at room temperature and at $0{ }^{\circ} \mathrm{C}$, early or late clamping, and sampling from the chorionic vessels of the placenta)

\section{Material and methods}

In the first study (investigation A), four arterial and venous samples were drawn in 10 vaginal deliveries.

I. Within 30 seconds of birth. These samples were cool-stored for a short period and analysed within 15 minutes.

\section{Curriculum vitae}

MARIA PEL was born in Middelburg, the Netherlands and studied at the medical faculty of the Free University, Amsterdam, from 1969 to 1976. She worked at the Antoni van Leeuwenhoek Hospital, Amsterdam, from 1977 to 1978 and at the Pathology Department of the University of Amster. dam from 1978 to 1979

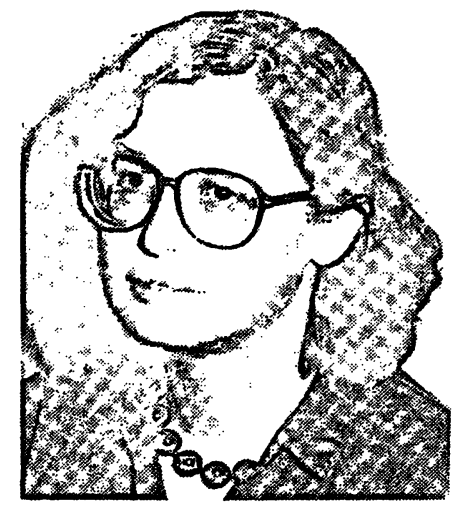

Since May 1979 she has been resident in Gynaecology and Obstetrics in the Wilhelmina Gasthuis, University of Amsterdam.

II. Within 60 seconds of birth. These syringes were stored for 30 minutes at room temperature, then cool-stored until testing (about 15 minutes).

III. A segment of the cord was resected directly after clamping, usually 3 to 5 minutes post partum. This segment was stored in the refrigerator for 30 minutes after which samples were drawn and tested within 15 minutes.

IV. After delivery and inspection, the placenta was stored in the refrigerator for 35 minutes post partum, after which blood samples were drawn from the chorionic vessels and tested within 15 minutes.

The second study is divided into three parts, B1, B2, and B3. B1: In 11 deliveries, a segment of the umbilical cord was clamped and isolated in the first minute post partum. Three venous 
and arterial samples were drawn in syringes and labelled I, II, and III.

Combination I was tested immediately, combination II after storage for $\mathbf{3 0}$ minutes on melting ice $\left(0^{\circ} \mathrm{C}\right.$.) and combination III after storage for 30 minutes at room temperature. B2: In 12 deliveries, a segment of the umbilical cord was clamped and isolated in the first minute post partum. This segment was subdivided into three specimens; from the first specimen one venous and one arterial sample were drawn and tested immediately.

The second specimen was stored in a plastic bag on melting ice and the third specimen in a plastic bag at room temperature; after 30 minutes, an arterial and a venous sample were drawn from these stored specimens, and tested.

B3: In 14 vaginal deliveries, an arterial and venous sample were drawn from the cord not more than 30 seconds after delivery (I). The cord was not clamped until after 3 minutes and then further arterial and venous samples were taken (II). Immediately after the placenta had been delivered and inspected, an arterial and venous sample were drawn from the chorionic vessels (III).

All samples were drawn under strictly anaerobic conditions in polyethylene syringes, which had been previously coated with $0.05 \mathrm{ml}$. heparin solution (concentration $50 \mathrm{mg} / \mathrm{ml}$.). At least $0.5 \mathrm{ml}$. but preferably $1.0 \mathrm{ml}$. of blood was drawn in each case. The heparin concentration therefore fluctuated from 2.5 to $5 \mathrm{mg} / \mathrm{ml}$.

In each series of tests however, the same amount of blood was drawn, thereby ensuring a constant heparin concentration in each sample of that series. All samples were tested by one person (first author) using the same apparatus, an AVL 937. A full blood-gas analysis was performed. All samples were tested twice. $\mathrm{pH}$-value differences of more than 0.005 between the two estimations were not accepted.

Statistical analysis was performed using the Student t-test.

\section{Results}

Investigation A (Tab. I): When blood is sampled 1 minute post partum instead of immediately and stored at room temperature for 30 minutes, the $\mathrm{pH}$ level is significantly lower (mean $\Delta \mathrm{pH}$ art. 0.050 and ven. 0.025) than in samples drawn immediately and cool-stored for not more than 15 minutes.

Tab. I. (Investigation A). Decrease in arterial and venous blood $\mathrm{pH}(\Delta \mathrm{pH})$, sampled and stored by three different procedures, compared with blood samples drawn and tested immediately post partum $(n=10)$.

\begin{tabular}{llcc}
\hline & Arterial & & \\
& I-II & I-III & I-IV \\
Mean $\Delta \mathrm{pH}$ & 0.050 & 0.090 & 0.109 \\
SD̃. & 0.028 & 0.059 & 0.065 \\
Range & $0.02-0.10$ & $0.01-0.18$ & $0-0.19$ \\
p & $<0.0005$ & $<0.0005$ & $<0.0005$ \\
& & & \\
& Venous & & \\
Mean $\Delta$ pH & I-II & I-III & I-IV \\
SD. & 0.025 & 0.042 & 0.110 \\
Range & 0.032 & 0.051 & 0.067 \\
p & $-0.02-0.09$ & $-0.03-0.13$ & $0.03-0.26$ \\
\hline
\end{tabular}

I: Sampled and tested immediately

II: Sampled within 60 seconds post partum, stored for 30 minutes at room temperature

III: Sampled from a segment of the umbilical cord, clamped several minutes post partum and coolstored for $\mathbf{3 0}$ minutes

IV: Sampled 35 minutes post partum from the chorionic vessels of the placenta (being cool-stored after delivery).

The combination of late clamping (3-5 minutes post partum), storage of the blood in an isolated segment of the cord and storage of the syringes at room temperature for a short interval (15 minutes) results in a significant decrease in the $\mathrm{pH}$ (mean $\Delta \mathrm{pH}$ art. 0.090 and ven. 0.042 ) when compared with samples drawn immediately and cool-stored for not more than 15 minutes.

When blood is sampled from the chorionic vesșels of the placenta which is cool-stored for up to 35 minutes after delivery, the $\mathrm{pH}$ level is significantly lower (mean $\Delta \mathrm{pH}$ art. 0.109 and ven. 0.110 ) than in samples drawn immediately and cool-stored for not more than 15 minutes.

\section{Investigation $B$}

Investigation B1 (Tab. II): Storage of the blood in syringes on ice for 30 minutes produced no significant decrease in the $\mathrm{pH}$. Storing at room tempera- 
ture for 30 minutes decreased the $\mathrm{pH}$ in both arterial and venous samples. The decrease was slight but significant (mean $\Delta \mathrm{pH}$ art. 0.018 and ven. 0.016).

Tab. II. (Investigation B1). Decrease in arterial and venous cord blood $\mathrm{pH}(\Delta \mathrm{pH})$, when blood is stored in syringes at $0^{\circ} \mathrm{C}$ and at room temperature $(n=11)$.

\begin{tabular}{lllll}
\hline & Arterial & \multicolumn{3}{c}{ Venous } \\
& I-II & I-III & I-II & I-III \\
Mean & & & & \\
$\Delta \mathrm{pH}$ & 0.003 & 0.018 & 0.005 & 0.016 \\
SD. & 0.011 & 0.017 & 0.008 & 0.014 \\
Range & $-0.02-0.01$ & $0-0.15$ & $-0.02-0.01$ & $0-0.04$ \\
p & 0.08 & $<0.005$ & 0.096 & $<0.05$ \\
& (n.s.) & & (n.s.) & \\
\hline
\end{tabular}

I: Sampled and tested immediately

II: Cord blood in syringes stored for 30 minutes at $0^{\circ} \mathrm{C}$.

III: Cord blood in syringes stored for $\mathbf{3 0}$ minutes at room temperature.

Investigation B2 (Tab. III): Storage of blood in isolated segments of the umbilical cord, both on melting ice and at room temperature, caused a significant decrease in the $\mathrm{pH}$ (mean $\Delta \mathrm{pH}$ art. at $0{ }^{\circ} \mathrm{C} 0.035$, room temperature 0.032 , mean $\Delta \mathrm{pH}$ ven. $0^{\circ} \mathrm{C} 0.013$, at room temperature 0.021 ).

Tab. III. (Investigation B2). Decrease in arterial and venous cord blood $\mathrm{pH}(\Delta \mathrm{pH})$, when blood is stored in segments of the umbilical cord, at $0^{\circ} \mathrm{C}$ and at room temperature $(n=12)$.

\begin{tabular}{lcccc}
\hline & Arterial & \multicolumn{3}{c}{ Venous } \\
& I-II & I-III & I-II & I-III \\
Mean & & & & \\
$\Delta \mathrm{p} \overline{\mathrm{H}}$ & 0.035 & 0.032 & 0.013 & 0.021 \\
SD. & 0.047 & 0.045 & 0.015 & 0.018 \\
Range & $-0.01-$ & $-0.03-$ & $-0.01-$ & $-0.02-$ \\
& 0.15 & 0.14 & 0.04 & 0.05 \\
$\mathrm{p}$ & $<0.05$ & $<0.05$ & $<0.05$ & $<0.005$ \\
\hline
\end{tabular}

I: Sampled and tested immediately

II: Sampled from a segment of the cord stored at $0^{\circ} \mathrm{C}$ for 30 minutes

III: Sampled from a segment of the cord stored at room temperature for $\mathbf{3 0}$ minutes

Investigation B3 (Tab. IV): Blood samples drawn 3 minutes post partum from the previously unclamped cord showed a significant decrease in the arterial and venous $\mathrm{pH}$ (mean $\Delta \mathrm{pH}$ art. 0.44 , ven. 0.011 ) when compared with samples taken immediately (within 30 seconds after birth).
Samples drawn from the chorionic vessels also showed a decrease in arterial and venous $\mathrm{pH}$ (mean $\Delta \mathrm{pH}$ art. 0.047 , ven. 0.042 ) when compared with samples drawn immediately.

Tab. IV. (Investigation B3). Decrease in arterial and venous cord blood $\mathrm{pH}(\Delta \mathrm{pH})$, when blood is sampled 3 minutes post partum (late clamping), and from the chorionic vessels of the placenta $(n=14)$.

\begin{tabular}{lcccc}
\hline & Arterial & & \multicolumn{2}{c}{ Venous } \\
& I-II & I-III & I-II & I-III \\
Mean & & & & \\
$\Delta \mathrm{pH}$ & 0.044 & 0.047 & 0.011 & 0.042 \\
SD. & 0.031 & 0.044 & 0.015 & 0.043 \\
Range & $-0.01-$ & $-0.07-$ & $-0.01-$ & $-0.01-$ \\
& 0.10 & 0.11 & 0.03 & 0.10 \\
p & $<0.005$ & $<0.005$ & $<0.05$ & $<0.005$ \\
\hline
\end{tabular}

I: Sampled and tested immediately

II: Sampled three minutes post partum from the previously unclamped cord

III: Sampled from the chorionic vessels of the placenta

\section{Discussion}

Conditions affecting the results of $\mathrm{pH}$ estimation have been investigated by others:

- Heparin: SIGGAARD ANDERSEN [10] and VY QUY NHAN et al. [12] both demonstrated a decrease in $\mathrm{pH}$ when heparin concentration increased. As can be seen above, we ensured that the heparin concentration was constant within any series of tests, although it did fluctuate from series to series.

- Storage: Our findings are in accordance with most other authors $[6,10,12]$.

Only SCHURZ et al. [9] found no significant changes after storing the blood for one hour at either $38^{\circ} \mathrm{C}, 20^{\circ} \mathrm{C}$, or $0^{\circ} \mathrm{C}$.

- Storage in the cord: SCHURZ et al. [9] are the only authors who have previously investigated this factor. Storage of the cord for 30 minutes in a refrigerator or at room temperature led to a decrease in the $\mathrm{pH}$ of only 0.001 in that study. Our findings are quite different (Tab. III).

This could result from the fact that SCHURZ cannulated 'an umbilical vessel', probably the vein, since this is wider and more easily cannulated, and furthermore began the sampling after 15 minutes. We found the decrease in the arterial $\mathrm{pH}$ much larger than in the venous $\mathrm{pH}$. We ascribe this to the 
greater metabolic demand of the more muscular arterial wall.

- Early or late sampling: The decrease of the $\mathrm{pH}$ in the first minutes of extrauterine life is known from various other investigations, either by cannulating catheters into the newborn or the umbilical vessels $[7,8,11]$ or by heel blood capillary samples $[1,4]$, and continuous tissue $\mathrm{pH}$ determination. KARLBERG [4] calls this the metabolic hangover.

The difference we found between the $\mathrm{pH}$ of arterial blood drawn immediately and after 3 minutes could be ascribed to this decreasing tendency of the neonatal blood $\mathrm{pH}$.

- Sampling from the placenta: This has not been investigated before. We found a considerable decrease in the arterial and the venous $\mathrm{pH}$, when compared with samples drawn from the cord immediately after birth.

An interesting feature is the difference in decrease in the $\mathrm{pH}$ between arterial and venous blood, when stored in the cord (investigation B2), and when sampled three minutes post partum (investigation B3). In both cases the arterial decrease is much larger. In investigation B2, this difference could be ascribed to the greater metabolic demand of the arterial wall (see above), but in investigation B3 where the blood was sampled three minutes post partum from the unclamped cord, the considerable decrease was probably due mainly to the output of neonatal blood, with a decreasing $\mathrm{pH}$ the first minutes post partum ('metabolic hangover') $[1,2$, $3,9]$. The much less pronounced decrease in the venous $\mathrm{pH}$ could be ascribed to gas exchange in the still functioning placenta. When blood is taken from the chorionic vessels of the placenta, however, the decrease in the arterial and venous $\mathrm{pH}$ is considerable and almost equal. This could be explained by the metabolic demands of the placenta, the maternal blood supply and the fetal circulation in the placenta having stopped some time before.

In investigation $\mathbf{A}$ the combined effect of all these factors which can cause a decrease in $\mathrm{pH}$ is shown. As can be seen above, every single form of delay with regard to sampling and analysing umbilical cord blood lowers the $\mathrm{pH}$. It is therefore not surprising that the $\mathrm{pH}$ of blood drawn one minute post partum and stored for half an hour at room temperature showed a decrease of 0.05 arterial and 0.025 venous, a combination of late clamping ('metabolic hangover') and storage at room temperature.

These changes were even more severe when blood was drawn from an isolated segment of the cord, clamped several minutes post partum and coolstored for 30 minutes: A mean decrease of 0.09 arterial and 0.042 venous, a combination of late clamping ('metabolic hangover'), and storage in the cord.

Blood samples from the chorionic vessels of the cool-stored placenta gave the lowest results: A mean decrease of 0.109 arterial and 0.110 venous. This probably results from the metabolic demands of the placental tissue, especially since the placental volume is too large to be effectively chilled in 30 minutes or less.

\section{Conclusion}

We have shown that a delay in sampling umbilical blood from the cord and storage of the cord for 30 minutes at room temperature, or on ice, and storage of the blood in syringes at room temperature for 30 minutes, all cause a decrease in the result of the umbilical cord $\mathrm{pH}_{\text {r }}$.

We have also shown a decrease when blood is taken from the chorionic vessels of the placenta.

The results of our study indicate that a reliable estimation of $\mathrm{pH}$ can only be obtained when all above mentioned factors are avoided by puncturing the cord immediately after birth, storing the samples on ice, and testing them within 30 minutes. Since the immediate attention of the obstetrician after birth in routine obstetrical practice is focused on the newborn and the mother, it is often quite impossible to avoid delay. Its elimination will require extra staff.

Either the utmost care must be taken to obtain a reliable result of umbilical cord $\mathrm{pH}$, or the results must be considered with circumspection. 


\section{Summary}

The $\mathrm{pH}$ of arterial and/or venous umbilical cord blood is an important parameter for evaluating obstetrical outcome. However, little attention is payed to the reliability of the result.

In the Wilhelmina Gasthuis in Amsterdam, Holland, we performed a systematic investigation into the influence of various circumstantial factors on the ultimate result of the cord $\mathrm{pH}$.

At first (investigation A) blood samples were drawn and tested in four different ways (I: drawn and tested immediately; II: drawn one minute post partum, stored at room temperature for 30 minutes; III: sampled from a late clamped segment of the cord, which had been coolstored for $\mathbf{3 0}$ minutes after birth; IV: sampled $\mathbf{3 5}$ minutes post partum from the chorionic vessels of the placenta, which had been cool-stored after delivery).

The results of II, III and IV were compared to value I and we found significant, considerable decreases in the $\mathrm{pH}$.

However, we wanted to evaluate some factors separately; in investigation B we studied the influence of storage of cord blood in syringes at $0^{\circ} \mathrm{C}$ and at room temperature for 30 minutes $\left(B_{1}\right)$, the storage of cord blood in isolated segments of the cord itself at $0^{\circ} \mathrm{C}$ and at room temperature for 30 minutes $\left(B_{2}\right)$, and the influence of early or late (i.e. 3 minutes p.p.) sampling from the cord and sampling from the placenta $\left(B_{3}\right)$.

We found that storage of the cord blood in syringes $\left(B_{1}\right)$ at $0^{\circ} \mathrm{C}$ for 30 minutes gave no significant decrease and at room temperature a slight, but significant decrease (mean $\Delta \mathrm{pH} 0.018$ arterial and 0.016 venous).

Storage of the cord blood for 30 minutes in segments of the cord $\left(\mathrm{B}_{2}\right)$ caused a significant decrease in the $\mathrm{pH}$ both at $0^{\circ} \mathrm{C}$ and at room temperature (mean $\Delta \mathrm{pH}$ art. 0.035 and ven. 0.013 at $0^{\circ} \mathrm{C}$, mean $\Delta \mathrm{pH}$ art. 0.032 and ven. 0.021 at room temperature).

Late sampling $\left(\mathrm{B}_{3}\right)$ also gave a considerable significant decrease (mean $\Delta \mathrm{pH}$ art. 0.044 , ven. 0.011 ), and, lastly, sampling from the chorionic vessels of the placenta $\left(B_{3}\right)$ also gave a significant decrease (mean $\Delta \mathrm{pH}$ art. 0.047 and ven. 0.042).

Our findings are compared with those in the literature; we discuss some of the mechanisms which cause decreases in the $\mathrm{pH}$.

We stress the fact that, in routine obstetrical practice, it can be very difficult to avoid delay in sampling and/or testing the cord blood.

As every form of delay decreases the reliability with which cord blood $\mathrm{pH}$ can be determined, routinely obtained results may not be reliable and should be considered with circumspection.

Keywords: Acid-base balance, clinical problems, effect of storage, fetal monitoring, newborn, placenta, umbilical cord, umbilical cord blood $\mathrm{pH}$.

\section{Zusammenfassung}

Zur Reliabilität der pH-Messung im Nabelschnurblut

Der pH-Wert in der Nabelarterie bzw. -vene ist ein wichtiger Parameter bei der Beurteilung des kindlichen Zustandes unmittelbar nach der Geburt. Wenig beachtet wird jedoch die Zuverlässigkeit des Meßergebnisses.

Im Wilhelmina Gasthuis in Amsterdam, Holland, führten wir eine systematische Untersuchung durch, die den Einfluß verschiedener Zufallsfaktoren auf das Ergebnis der pH-Messung im Nabelschnurblut klären sollte. Zunächst wurden in Studie A auf 4 verschiedene Arten Blutproben entnommen und ausgewertet (I: Blutentnahme und pH-Bestimmung unmittelbar post partum; II: Blutentnahme 1 Minute post partum, Probe 30 Minuten bei Raumtemperatur; III: Blutentnahme aus einem spät abgeklemmten Nabelschnurabschnitt, der für 30 Minuten nach der Geburt kühl aufbewahrt wurde; IV: Blutentnahme 35 Minuten post partum aus den Choriongefäßen der Plazenta, die nach der Entbindung kühl gelagert wurde).

Die Ergebnisse aus II, III und IV wurden mit denen von I verglichen und zeigten einen erheblichen signifikanten pH-Abfall.

Wir wollten jedoch einige Einflußgrößen getrennt von einander betrachten. In Studie B untersuchten wir den Einfluß der Aufbewahrung der Blutproben: $\dot{B}_{1}$ vergleicht Aufbewahrung über 30 Minuten bis zur Auswertung in Spritzen bei $0^{\circ} \mathrm{C}$ und bei Raumtemperatur. $B_{2}$ vergleicht Aufbewahrung für 30 Minuten in isolierten Nabelschnurabschnitten bei $0^{\circ} \mathrm{C}$ und bei Raumtemperatur. In $\mathrm{B}_{3}$ wird der Einfluß einer frühen bzw. späten, d.h. 3 Minuten post partum erfolgten Probenentnahme aus der Nabelschnur und aus der Plazenta untersucht.

Werden die Proben wie in $B_{1}$ in Spritzen für 30 Minuten bei $0^{\circ} \mathrm{C}$ aufbewahrt, zeigt sich kein signifikanter Abfall, während bei Raumtemperatur der pH-Wert geringfügig, jedoch signifikant abnimmt (mittleres $\Delta$ beim arteriellen pH 0,018 , beim venösen pH 0,016 ).

Die Aufbewahrung in Nabelschnurabschnitten wie in $B_{2}$ führt sowohl bei $0^{\circ} \mathrm{C}$ wie auch bei Raumtemperatur zu einer signifikanten $\mathrm{pH}$-Wert-Erniedrigung (mittleres $\Delta$ für den $\mathrm{pH}$ bei $0^{\circ} \mathrm{C}$ im arteriellen Blut 0,035 , im venösen Blut 0,013 ; mittleres $\Delta$ für den $\mathrm{pH}$ bei Raumtemperatur im arteriellen Blut 0,032, im venösen Blut 0,021).

Die späte Probenentnahme wie in $B_{3}$ führt ebenfalls $z u$ einer erheblichen Senkung des pH-Werts (mittleres $\Delta$ für den $\mathrm{pH}$ bei Abnahme aus der Nabelschnur im arteriellen Blut 0,044, im venösen Blut 0,011; mittleres $\Delta$ für den $\mathrm{pH}$ bei Abnahme aus den Choriongefäßen der Plazenta im arteriellen Blut 0,047, im venösen Blut 0,042).

Die Ergebnisse werden mit der Literatur verglichen und einige Mechanismen, die eine $\mathrm{pH}$-Wert-Senkung verursachen, diskutiert.

Es wird nachdrücklich betont, daß in der geburtshilflichen Routine eine Verzögerung bei der Probenentnahme bzw. -auswertung häufig nicht zu vermeiden ist.

Da jede Verzögerung die Reliabilität der pH-Wert-Messung herabsetzt, sind routinemäßig erhobene Ergebnisse nicht immer verläßlich und sollten mit Vorsicht beurteilt werden.

Schlüsselwörter: Einfluß der Probenaufbewahrung, fetales Monitoring, klinische Komplikationen, Nabelblut-pH, Nabelschnur, Neugeborenes, Plazenta, Säure-Basen-Gleichgewicht. 


\section{Résumé}

Fiabilité des résultats du pH du cordon ombilical

Le pH du sang artériel et/ou veineux du cordon ombilical est un paramètre important pour évaluer le devenir obstétrical. Toutefois, on porte peu d'attention à la fiabilité des résultats.

Les auteurs ont entrepris l'étude systématique de l'influence d'un certain nombre d'éléments sur le résultat définitif du $\mathrm{pH}$ au cordon, à la Wilhelmina Gasthuis d'Amsterdam, en Hollande. En première approche (Etude A) des échantillons de sang ont été prélevés et analysés de 4 façons différentes (I: prélèvement et examen sur le champ; II: prélèvement 1 minute après la naissance, conservation à température ambiante pendant 30 minutes; III: prélèvement à partir d'un fragment de cordon clampé tardivement et conservé au froid pendant 30 minutes après la naissance; IV: prélèvement 35 minutes après l'accouchement sur les vaisseaux chorioniques du placenta conservé au froid après la délivrance).

Les résultats des situations II, III et IV ont été comparés à ceux de I et une diminution important du $\mathrm{pH}$, significative a été mise en évidence.

Toutefois, il est souhaitable d'apprécier certains éléments séparément. Dans l'étude B les auteurs ont étudiés l'influence du stockage du sang du cordon dans des seringues à $0^{\circ} \mathrm{C}$ et à température ambiante pendant 30 minutes $\left(B_{1}\right)$, du stockage du sang dans des fragments isolés du cordon à $0^{\circ} \mathrm{C}$ et à température ambiante pendant 30 minutes $\left(B_{2}\right)$, et l'influence du prélèvement précoce ou tardif (c'est-à-dire 3 minutẹs, post-partum) sur le cordon ou le placenta $\left(B_{3}\right)$.

Les résultats montrent que le stockage du sang dans des seringues $\left(B_{1}\right)$ à $0^{\circ} \mathrm{C}$ pendant 30 minutes n'entraine pas de diminution significative et à température ambiente une légère diminution significative (moyenne $\Delta \mathrm{pH}: 0,018$ en artériel et 0,016 en veineux).

Le stockage du sang du cordon pendant 30 minutes dans des fragments de cordon $\left(\mathrm{B}_{2}\right)$ provoque une diminution significative du $\mathrm{pH}$ à la fois à $0^{\circ} \mathrm{C}$ et à température ambiante $\left(\Delta \mathrm{pH}\right.$ moyen art.: 0,035 et vein.: 0,013 à $0^{\circ} \mathrm{C}$; $\Delta \mathrm{pH}$ moyen art.: 0,032 et vein.: 0,021 à température ambiante).

Le dernier mode de prélèvement $\left(\mathrm{B}_{3}\right)$ produit une diminution importante significative $(\Delta \mathrm{pH}$ art. moyen: 0,044 et vein.: 0,011 ) de même que finalement le prélèvement à partir des vaisseaux chorioniques du placenta $\left(B_{3}\right)(\Delta \mathrm{pH}$ moyen art. 0,047 et vein.: 0,042).

Ces donnés soṇt comparées à celles de la littérature; les auteurs discütent quelques mécanismes qui provoquent une diminution du $\mathrm{pH}$.

Les auteurs insistent sur le fait que en pratique obstétricale de routine, il est très difficile d'éviter des délais dans le prélèvement et/ou l'analyse du sang du cordon.

Or, comme tout délai diminue la fiabilité de la détermination du pH du sang du cordon, les résultats obtenus en routine peuvent ne pas être fiables et doivent être interprétés avec circonspection.

Mots-clés: Aspects cliniques, cordon ombilical, effets du stockage, équilibre acido-basique, nouveau-né, pH du sang du cordon ombilical, placenta.

Acknowledgements: We would like to thank Mr. G. HART of the department of Medische Fysica of the University of Amsterdam for the statistical analysis, and Dr.H. BARROWCLOUGH and Mrs. JO SCOTT for revising the English text.

\section{Bibliography}

[1] ECKENHAUSEN, F. W.: A study of the perinatal acid-base equilibrium. Thesis, University of Leiden 1969

[2] JANACEK, P., H. BOSSART: Clinical aspects of continuous tissue $\mathrm{pH}$ measurements of the newborn and the fetus. Arch. Gynecol. 226 (1978) 121

[3] HUISJES, H. J., J. G. AARNOUDSE: Arterial or venous umbilical $\mathrm{pH}$ as a measure of neonatal morbidity. Early Human Development 3 (1979) 155

[4] KARLBERG, P.: Management of the preterm infant in the labour ward. In: STEINBERG, Z. K. (ed.): Perinatal Medicine. Proceedings 14th Congress of Perinatal medicine, Prague August 1974. Thieme, Stuttgart 1975

[5] KUBLI, F., H. RÜTTGERS, H. D. HENNER: Clinical aspects of fetal acid-base balance during labor. In: LONGO, L. D., H. BARTELS (eds.): Respiratory gas exchange and blood flow in the placenta. US Department of Health, Education and Welfare Publications, Bethesda 1972

[6] SATO, I., E. SALING: Changes of pH-values during storage of fetal blood samples. J. Perinat. Med. 3 (1973) 18

[7] SCHURZ, A. R., TH. REICH, ${ }^{\circ}$ E. HOCHULI: Veränderungen im Säurebasenstatus der Nabelarterie bei Früh- und Spätabnabelung. Z. Geburtsh. Perinat. 177 (1973) 177
[8] SCHURZ, A. ํ., M. TROCKENBACHER, TH. REICH: Das Verhalten des Säurebasenstatus der Nabelgefäße in der Nachgeburtsperiode. Z. Geburtsh. Perinat. 178 (1974) 377

[9] SCHURZ, A. R., M. TROCKENBACHER, TH. REICH: Gasanalytische Probleme beim Storing von Nabelschnurblutproben. Z. Geburtsh. Perinat. 180 (1976) 412

[10] SIGGAARD AANDERSEN, O.: Sampling and storing of blood for determination of acid base status. Scandinav. J. Clin. Lab. Investigation 13 (1961) 196

[11] THALME, B.: Acid-base and electrolyte balance during the first 15 minutes of extra-uterine life. Acta Obstet. Gynec. Scand. 45 Suppl. 8 (1966) 77

[12] VU QUY NHAN, H.W.A. DE BRUYN, H. J. HUISJES: Umbilical blood gas analysis: I. Effect of storage of samples on outcome. Int. J. Gynaecol. Obstet. 17 (1980) 479

Received December 1, 1982. Revised January 4, 1983. Accepted March 4, 1983.

M. Pel

Wilhelmina Gasthuis (Dep. Obst. \& Gyn.)

Eerste Helmersstraat 104

1054 EG Amsterdam

The Netherlands 